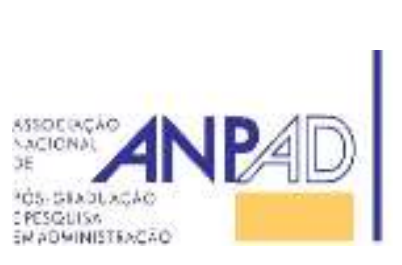

Available online at http://www.anpad.org.br/bar

BAR, Rio de Janeiro, v. 14, n. 2, art. 2, e160092, 2017

http://dx.doi.org/10.1590/1807-7692bar2017160092

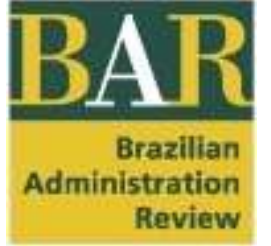

\title{
Strategic Management in Hospitals: Tensions between the Managerial and Institutional Lens
}

Lucilaine Maria Pascuci ${ }^{1}$

Victor Meyer Júnior ${ }^{2}$

João Marcelo Crubellate ${ }^{3}$

Universidade Federal do Espirito Santo ${ }^{1}$ Pontifícia Universidade Católica do Paraná ${ }^{2}$

Universidade Estadual de Maringá ${ }^{3}$

Received 17 September 2016; received in revised form in 20 June 2017 (this paper has been with the authors for two revisions); accepted in 28 June 2017; first published online 11 July 2017. Editor's note. George Bedinelli Rossi served as Action Editor for this article. 


\begin{abstract}
The relationship between organizations and their environments has been object of study by scholars of the theory of organizations and in discussions concerning organizational strategy. When these perspectives come together, two sets of different but overlapping forces in the strategy formation process are highlighted. The purpose of this study is to analyze how strategic management contributed to reducing tensions derived from managerial and institutional logics in philanthropic hospitals. It is a comparative case study, with a multi-method approach. The data were examined using narrative and document analysis techniques. The analysis indicated that integrating organizational-managerialist and institutional perspectives raises continuous tensions within organizations with a direct impact on managerial decisions, strategic actions and performance. The strategic management approach should be sensitive enough to recognize and reduce these tensions and find ways to integrate them more effectively. This effort requires a combination of strong leadership skills and appropriate managerial tools. Flexibility, adaptability, creativity and informal interactions should be the basis of any strategic initiatives. Daring and innovation of the hospitals - more than acquiescence - are essential to their social and financial sustainability.
\end{abstract}

Key words: strategic management; institutionalism; managerialism; tensions; hospitals. 


\section{Introduction}

Hospitals can be seen as social organizations as well as institutions with an increasingly important role to society (Etzioni, 1964). As organizations specializing in providing essential health services, learning and research centers, there has been growing criticism of the quality of their services and the cost to patients and the state (Correia, 2012). Critical factors are today challenging hospital manager like the high operational costs, internal inefficiencies and growing demand for diversified (Porter \& Teinsberg, 2006).

As institutions, hospitals have a social mission to fulfill their goals by providing quality services to the needy when required. How well their institutional and organizational mission (King, 2015) is accomplished determines their legitimacy in the eyes of the community. In this context, multiple stakeholders and variables in the relationship between hospitals and their environments have a significant impact on the success of the strategies they develop (Jarzabkowski \& Fenton, 2006; Meyer, Pascuci, \& Mamédio, 2016).

The relationship between organizations and their environments was one of the first concerns in the Theory of Organizations and the debate on organizational strategy (Greenwood, Hinings, \& Whetten, 2014). Different approaches have offered explanations regarding this relationship. From the three main approaches highlighted by Wilson (1992), the one that guides this study has to do with understanding the environment as the result of objective variables. However, the relationship between organization and environment occurs through the interpretation of these variables by managers and members of the organization, where elements of cognition and interpretation become highly relevant (Binder, 2007; Greenwood, Raynard, Kodeih, Michelotta, \& Lounsbury, 2011; Hinings \& Greenwood, 1988; Oliver, 1991).

In recent years, Brazilian hospitals have changed their image from a welfare organization to a professional organization (Meyer et al., 2016). However, in this process, professionalization has been translated predominantly as enhancing financial performance, from the adoption of management methodologies from companies operating in the market (managerialist methodologies) (French \& Grey, 1996; Locke \& Spender, 2011), focusing mainly on efficiency and profitability. Nevertheless, these philanthropic institutions are subject to regulations and face the challenge of fulfilling of their institutional mission while achieving financial sustainability (Meyer, Pascuci, \& Murphy, 2010; Meyer et al., 2016).

Managers practicing strategic management face a twofold challenge: the organizational complexity of hospitals and learning how to transform intentions into actions and meaningful outcomes with effectiveness and legitimacy while remaining committed to the organization's core values and beliefs (King, 2015). Strategic practice occurs in an interdependent way based on cooperation and interrelationships of its elements in an environment that is neither inert nor stable, and far less predictable. As loosely coupled systems (Orton \& Weick, 1990), professional (Mintzberg, 1994) and pluralistic (Jarzabkowski \& Fenton, 2006) organizations' strategic decisions and practices within hospitals have strong political connotations and their results depend on a complex interaction of top management team (TMT) and health professionals throughout the organization. These characteristics strengthen the importance of elements such as interpretation of reality, improvisation and learning (McDaniel, 2007).

In that context, the purpose of our study is to analyze the association between managerial and institutional logics and the strategic management in hospitals as pluralistic organizations. More specifically, this study seeks to answer the following research question: how did strategic management contribute to reducing tensions derived from managerial and institutional logics? To do so, we identified the main tensions resulting from the conflict of managerial and institutional logics and their implications in the strategic management of the hospitals.

Our perspective in this paper is neither rationalistic (based only on isolated organizational choices) nor strictly contingencialist (advocating a direct influence of the environment on 
organizations). Instead, we propose a balanced approach that combines the rationale that guides cognition and strategic actions, and the institutional logics that are unfolded recursively or actualized through strategic practices.

Considering the complexity and plurality of their organizational and environmental context, we can expect specific arrangements of managerial and institutional attributes operating in the strategic management of hospitals, not only due to their diversity but also to the ambiguity of their objectives, their stakeholders' beliefs and interests (Binder, 2007; Chandler \& Hwang, 2015; Greenwood et al., 2011).

This paper contributes to the field by identifying and examining tensions derived from managerial and institutional approaches based on the strategic management practices experienced by philanthropic Brazilian hospitals inserted in a dynamic and sometimes unpredictable environment. This study investigates what went right and wrong in the adoption of managerialist practices in hospitals, seeking to demonstrate how managerial and institutional logics can achieve a balance in the management of social institutions such as hospitals.

\section{Organization, Strategies and the Environment}

Wilson (1992) highlights three main approaches to understanding the relationship between organizations and their environments. The first identifies the environment as an objective set of variables external to the organization to which the organization needs to adapt in order to be successful. The second stresses that the organizational environment continues to be understood as a set of objective variables. However, the relationship between organization and environment occurs through the interpretation of these variables by the managers and members of the organization, with emphasis on the elements of cognition and interpretation (see also Hinings \& Greenwood, 1988; Lieberman \& Asaba, 2006; Oliver, 1991; Pache \& Santos, 2010). The third approach views the environment as a product of organizational processes. In this sense, the environment tends to be understood as a construct or as socially or cognitively enacted by the members of the organization (Weick, 1979).

For some time now, the relationship between organizations and their environments has been studied by scholars of organization theory and been the object of discussions concerning organizational strategy (Andersen, 2004; Porter, 1980). The junction of these analysis perspectives has resulted in two sets of different but overlapping forces in management, especially in strategy development and practices.

On the one hand, there is a set of rationalist organizational forces that concentrate on organizational performance; on the other, there is a set of institutional forces in which the environmental element is predominant. Although these are not the only explanatory elements of the strategy formation process, it is recognized that their implications challenge the transformation of intentions into actions. After all, being institutionally embedded (Greenwood et al., 2014; Peng, Sun, Pinkhan, \& Chen, 2009), the strategic decisions of agents are influenced not only by results from a purely economic viewpoint but also by aspects perceived as socially appropriate (Ang, Benischke, \& Doh, 2015; Lieberman \& Asaba, 2006).

The integration of strategic management and institutional theories introduces a challenge through its different conception of human agency (Battilana \& Leca, 2009). While strategic management theory assumes the existence of a high degree of human agency, in part of the institutional theory agency emerges, or is constrained or constituted by, environmental (cognitive, normative or legal) forces (Scott, 2001; Walker, Schlosser, \& Deephouse, 2014). One way of conciliating these different visions, proposed by Battilana and Leca (2009), is the adoption of a relational vision of human agency.

This challenge must not be seen as a theoretical contradiction, as institutional theory has increased the investigation of agency as a decisive explanation when it comes to understanding engagement in 
institutional entrepreneurship and institutional work (Lawrence, Suddaby, \& Leca, 2011), generating institutional dynamism and emergence (Quattrone, 2015).

Likewise, agency is important when explaining a firm's tactics and responses to institutional complexity (Faulconbridge \& Muzio, 2016; Greenwood et al., 2011; Pache \& Santos, 2010), changing institutions through everyday work (Smets, Morris, \& Greenwood, 2012) and rhetoric (Harmon, Green, \& Goodnight, 2015). It is even important when it comes to engendering institutional constraints (Walker et al., 2014).

In short, instead of considering the conduct of agents as broadly determined by institutional pressures, agents should be considered as incorporated into a social context to which they respond as a result of the situations they face. Therefore, in accordance with Battilana and Leca (2009, p. 270), this study adopts the premise that "actors are not only shaped by existing institutions, but might also, under certain conditions, shape those institutions".

\section{Managerial rationalistic lens}

What really stands out behind the rationalistic-managerialist lens is a set of essentially instrumentally rationalist practices, which focus on the optimization of alignment between decisions and actions along with control systems examining the outcomes. In this perspective, a rational idea of the representation of reality emphasizes the explicit and deliberate conception of goals as well as the logical sequence of actions, where formulation and implementation are different phases of the decision process (Mintzberg, 1978).

Nevertheless, this rationality does not provide an accurate explanation of the behavior of strategists, managers or even organizations. Cognitive, cultural and institutional factors can and normally do affect decisions, even when these decisions are made with rational intentions (Ruef \& Scott, 1998; Simon, 1957). It is equally important to consider that managerialist practices incorporate a different form of management based on rational assumptions that do not exist in many organizations. This is the case of complex and pluralistic organizations, whose non-linearity and multiple stakeholders with diverging interests (Meyer et al., 2016) limit the results and benefits of rational models imported from the management of machine like organizations.

Cognitive limits to rational action have been expanded by Mintzberg (1987) based on the characterization of strategy as a continuous and adaptive process and by considering the strategist as a craftsman. In the strategy process, each strategist inevitably constructs meanings and uses them to interpret the situations in his or her own way. Therefore, the materialization of strategic actions is greatly influenced by organizational agents' perception, interpretation, and choices (Weick, 1979), and by the specificities of the hospital as a complex and pluralistic context.

The consideration of man as a rationally limited agent could be considered critical to how strategies emerge and how they are put into practice by agents. In this context, the alignment between decision and action comes up against the multiple internal and external agents involved in the decision process, the vested interests and the different interpretations of reality of these groups (Hinings \& Greenwood, 1988; Weick, 1976). Thus, in many cases, strategies are not defended for what they are but mainly for what they symbolize to the organization (Wildavsky, 1973).

\section{Institutional lens}

From an institutional analysis perspective, the study of strategy opens up a wide range of possibilities that have been developed in parallel and in unison with the central approaches of this organizational phenomenon.

Specifically about strategy research, Peng, Sun, Pinkhan and Chen (2009) argue for an institutionbased view of strategic decisions, in which managers and organizations actively and rationally "pursue 
their interests and make strategic choices within the formal and informal constraints in a given institutional framework" (p. 67).

Therefore, one of the most common errors in the critique of the new institutionalism is to consider that the environmental determination of organizational patterns, including those concerning strategy, reserves no space for choice. Actually, recent developments in institutional theory do not discard, and indeed require, conscious and active social actors who seek to achieve their goals. From this perspective, interests and capacity for agency are socially informed or constituted, not necessarily belonging to the individual but resulting from institutional experience (Peng et al., 2009). This happens when these individuals become socialized within a specific universe of institutions (archetypes, orders or logics) (Greenwood et al., 2014; Hinings \& Greenwood, 1988; Mohr \& White, 2008) and learn to live and compete socially therein.

Other studies conducted from an institutional perspective that is less committed to a contingency bias have identified the social actors more clearly in the historical background of organizations (Faulconbridge \& Muzio, 2016; Selznick, 1971; Zilber, 2002). Sometimes these studies even identify social actors as authors of themselves, of the organizations with which they are engaged and even of the institutional constraints to with their organizations have to respond (Lawrence et al., 2011; Walker et $a l ., 2014)$.

Recently, the institutional perspective has come to highlight analytical categories that are specifically connected to this central concern over the strategically guided participation of social actors in the institutionalization process, institutional change and even resistance to environmental pressures. There is a special focus on organizations' inner representation of institutional pressures (Pache \& Santos, 2010), local practices (Colyvas \& Maroulis, 2015; Smets et al., 2012), and interests (Dunn \& Jones, 2010), seeking to understand how organizations respond to institutional logics. Conjointly, these aspects suggest that political and symbolic aspects are essential, at least as important as instrumental aspects, in explaining the relationship between organization and environment.

\section{Strategic management in hospitals}

Studies have praised mechanicalness, rationality and predictability that cannot be applied to the majority of the traditional organizations and are impracticable in the case of hospitals (Etzioni, 1964). Hospitals are complex organizations due to their multiple and ambiguous objectives, the nature of their activities, and the diversity of professionals that perform their tasks by contributing in some way to the quality of the services provided. In hospitals, decisions and actions result from political, interpretive and symbolic aspects more than from essentially rationalistic approaches (McDaniel, 2007; Meyer et al., 2016).

In hospitals, as highly pluralistic contexts, organizational knowledge, legitimacy and social capital play an important strategic role. However, their accumulation involves a variety of internal and external stakeholders concerned with both internal conditions and the external environment. This context challenges the managers of these institutions to find the balance between the use of rationalmanagerial models, which balance social mission and sustainability with a set of institutional forces from the environment that are relevant to the managerial processes and its outcomes.

As social institutions, the strategic process in hospitals is represented by interactions, domination structures and exchanges of information. These elements are shared among the actors involved, including founders, top management team (TMT), professional specialists, the State and society, and are all organized through rules of association that delineate institutional frontiers and the differentiation principles employed within these limits. At the same time, these elements not only influence the social actors and their decisions. They are also affected by the strategic choices based on how agents interpret those elements.

Thus, the difference between managerial and institutional character is centered on the relative isolation of the former in relation to its social environment in following a predominantly mechanistic 
and instrumentally rational concept of its processes and procedures. It is also centered on technical efficiency as a parameter for evaluation versus a highly adaptive organic pattern in the institutional concept and the adoption of criteria of social legitimacy in the case of institutions (King, 2015; Selznick, 1971; Walker et al., 2014; Zoogah, Peng, \& Woldu, 2015). This change is the result of political processes and cognitive processes, even though these may not be consciously prepared (Harmon et al., 2015; Selznick, 1971).

Therefore, strategy development is not a neutral and linear way of coping with environmental pressures. Strategies are neither devices produced by the organization in direct response to that plurality of forces nor a product of environmental determination. They follow local arrangements of scripts, resources, means and ends dynamically constituted as a procedural logic that responds to the environment while experiencing and translating it, and translates it while responding to its pressures (Greenwood et al., 2011; King, 2015; Quattrone, 2015). The partial, non-fixed and intersubjective character of this unfolding process provides an adequate explanation for the differences in the processes of different organizations (King, 2015) even in the same field.

In addition to an institutional-based view of strategy, we wish to a focus on strategy as a central mediator between the institutional environment and organization attributes, in keeping with the suggestions of Greenwood, Raynard, Kodeih, Michelotta and Lounsbury's (2011). These authors recommend a focus on "how individual organizations experience and respond to the complexity that arises" (Greenwood's et al., 2011, p. 357) from the plurality of logics in the organizational environment. According to Pache and Santos (2010), the impact of diverse institutional logics on organizations partly depends on their representation within the organization, e.g., the influence of logics represented by fulltime professionals compared to the influence represented by part-time professionals or participants in a hospital (see also Greenwood et al., 2011).

This perspective suggests that strategic response is a function of how logics are given a voice within the organization and the resource dependence on the representatives of these logics within the organization, plus their interests and interpretation (Binder, 2007; Greenwood et al., 2011). Furthermore, even commitment to a preferred identity can act as a mediator for an organization's unfolding response logics (King, 2015). Strategic groups are affiliated with different institutional logics and internally reflect them and draw guidance and strength from them for strategic disputes. Therefore, the organization's character will be produced in this dynamic, reflecting the most powerful groups and their affiliation with specific logics.

\section{Methodology}

We adopt a comparative, qualitative case study design (Flyvbjerg, 2011) based on two Brazilian non-profit hospitals: Hospital Erasto Gaertner (HEG) and Hospital Pequeno Príncipe (HPP), both located in Curitiba, Paraná, Brazil. The hospitals provide health services and teaching. They also conduct research and are philanthropic hospitals.

The strategy for the selection of cases was Information-oriented Selection (Flyvbjerg, 2011, p. 307), seeking "to maximize the utility of information from small samples and single cases. Cases are selected on the basis of expectations about their information content", as also recommended by Lieberson (1992). Therefore, the cases were chosen because of, among the local hospitals, they are renowned nationwide in their specialist fields (oncology and pediatrics, respectively). In addition to the demand for hospitals renowned in their fields, the philanthropic nature also means that they treat patients from the Brazilian National Health Program, known as the SUS, administered by the Ministry of Health, whose payment policy has serious financial implications.

The regulations to which these organizations are subject result in the challenge of reconciling their institutional mission and sustainability. Besides their similar size, social mission (philanthropic), 
performance and core functions (teaching and research), professionalization of their management especially by the adoption of Strategic Planning (SP) approach. However, despite so many similarities, their efforts have had very different impacts on organizational performance.

The data were collected between May and October 2011 from three main sources: interviews, non-participant observation and documents to avoid possible bias resulting from a single data source. The primary data were collected during 32 interviews with actors (17 from HPP and 15 from HEG) from different hierarchical levels: top management, middle management and specialized professionals selected using non-probabilistic or intentional sampling.

One of the main criteria for selecting the interviewees was that they should participate directly in the hospital's strategic management at the corporate or sector level. Another criterion adopted was that they should be representatives of parties interested in changes considered critical (sources of tension) to the hospitals, as identified in the first interviews and through the strategic planning and minutes of the Administrative Council. Only administrative workers and professional specialists formally employed by the hospitals were considered as research subjects, given that the study focuses on aspects of hospital management.

The purpose of the interviews was to identify how the strategic process takes place at the hospitals in question, especially regarding the conciliation of the institutional and managerial look, from an analysis of the main strategies developed from 2005 to 2010 . The script of the interview was tested on two managers of a hospital organization not involved in the study, and adjustments were made. The interviews were held until we found that the information offered was being repeated by different interviewees from the hierarchical level, field and area of responsibility in management.

We also took notes as non-participant observers through constant participation of one of the authors in different types of management meetings, ranging from the sectors to meeting of the Administrative Council, where subjects related to the aspects of this study were addressed. These were recorded in field diaries for use during analysis. The transcriptions (interviews and field diaries) totaled 520 pages. Archives were also consulted. These included reports of activities, strategic plans, publications and information available on the hospitals' websites and/or provided by the interviewees.

The analysis was based on documental and Narrative Analysis (Manning \& Cullum-Swan, 1994), considered highly appropriate for transmitting knowledge on time, processes and changes (Herman, 2007). In the health care field, the implications for the life-and-death and social issues of patients overlap with those based solely on cause and effect relationships in the decision-making process. Therefore, the choice of this method also sought to consider the particular aspects of qualitative health research (Morse, 2011).

Of the different forms of Narrative Analysis, in this study we adopted meaning as the analysis technique. According to Eriksson and Kovalainen (2008, p. 218) this "refers to the content of the narrative (what happened, to whom, where and how)". Tsoukas and Hatch (2001) highlight that Narrative Analysis is highly appropriate for analyzing different dimensions of a phenomenon, and especially for analyzing complex systems, as is the case in this study.

We organized and interpreted the data to describe events, decisions and actions identified in the cases related to the development of strategies, managerial logics, institutional logics and tensions. For this purpose, a narrative (story) was constructed from each interview. These were interpreted and discussed by the authors. We then compared the content from the different narratives and, aided by the results of the document analysis, we constructed a general narrative for every aspect under study at each hospital. The variety of methods used for gathering data allowed the use of the Triangulation Approach to ensure the validity of the information. 


\section{Brazilian health care sector and cases researched}

Like any philanthropic Brazilian hospital, HPP and HEG are required to prove that at least $60 \%$ (or 70\%, in the case of a teaching hospital) of their installed capacity is given over to the SUS (Decreto n. 8.242, 2014; Lei n. 12.101, 2009). The SUS integrates the Brazilian public health system providing people with access to full services free of charge, especially to people in a low-income bracket. Compliance with this requirement guarantees that the institution is exempt from taxation and social security contributions, in accordance with federal, state and municipal legislation.

The services are paid for by the public sector after they have been provided. However, as public funding is limited to approximately $40 \%$ of the real cost of the health services, there is a real deficit in the hospitals' finances. Consequently, they have to seek other sources of income to break even and remain sustainable. The main features of both cases in question are presented below.

Table 1

\section{Profile of the Hospitals}

\begin{tabular}{lcc}
\hline Characteristic & HPP & HEG \\
\hline Foundation & 1919 & 1972 \\
\hline Position in Health Market & Largest Children's Hospital in Brazil & $\begin{array}{c}\text { Nationally and internationally } \\
\text { renowned for cancer treatment }\end{array}$ \\
\hline Type & Children's Hospital & Oncologic Hospital \\
\hline Clinical staff & $\sim 300$ & $\sim 134$ \\
\hline No. of beds & $\sim 370$ & $\sim 154$ \\
\hline No. of clinical staff per bed & 0.81 & 0.87 \\
\hline Average monthly attendance & $\sim 25,957$ & $\sim 30,400$ \\
\hline
\end{tabular}

Note. Source: elaborated by the authors based on Hospital Erasto Gaertner. (2014). Relatório anual 2013. Curitiba, Brasil: Erasto Gaertner; and Hospital Pequeno Príncipe. (2014). Relatório de atividades 2013 (Unpublished report). Curitiba, Brasil: Hospital Pequeno Príncipe.

After more than ninety years in operation, HPP retains the characteristics of a traditional family business, in addition to a strong organizational culture. Instead of a typical central administration, the hospital is managed by a Board of Directors, including representatives of the founding members. Some members of the Board and TMT assumed a social and political role at the local and national level.

Although there is SP, in practice the strategies implemented often result from the insights of the TMT regarding their interpretation and interactions with the environment rather than with previously set goals. Some important strategies developed during the period under study were chosen because of their significant impact on the economic and financial performance of the institution. They include: (a) the creation of the Research Institute (2005); (b) the expansion of the hospital (2006-2008); (c) the professionalization of the management (2008 onwards) and (d) a political lobby to change State Legislation in an attempt to gain special fiscal benefits for nonprofit social organizations.

The history of HEG is linked to the history of the Women's Cancer Combating Network (RFCC) founded in 1955 by local high society women to raise resources to build a hospital for cancer research and treatment. Both the Board and the TMT responsible for the management of HEG are elected and are made up mostly of professional specialists. The wide range of interests and divergences between the management and founding members has essentially resulted in a political management of the hospital. In the early 2000s, it became even more political, and this had a negative impact on the hospital's financial situation and institutional image. 
The turning point came in 2004 when a professionalization process began at the hospital. This involved people and processes and was guided by SP. These changes helped to improve the image of the hospital, change its internal culture, which up to that point had been one of welfare, and created conditions for organizational sustainability. Of the strategies adopted at this time, the most important and focus of this research were (a) the reformulation of the management model; (b) technological upgrading; (c) the implantation of certifications for specific qualities in the health sector; and (d) improved fund raising through closer ties to the government and society.

\section{Analysis}

The analysis was structured to present, initially, the main characteristics of the strategic management of the hospitals. From these, the main tensions could also be identified, as well as the practices adopted in their management and the results that were achieved.

\section{Characteristics of strategic management at the Hospitals}

Our analysis of the strategy management process revealed many similarities in how this process occurs at both hospitals. The main similarities are: (a) only the partial adoption of the SP; (b) the relevance of political interactions (more than plans) in strategic decisions; and (c) the influence of the institutional environment in strategic decisions and actions. The main difference identified involved processes. Whereas the strategic thinking at HPP showed informal characteristics and was concentrated in the TMT, at HEG a rational-choice model of strategic management was adopted, with rules, controls and meetings.

We found that the effective use of the SP as a strategic management mechanism at the hospitals clashed with characteristics usually seen as an important source of pressure on organizational strategy, structure and processes, as pointed out by Denis, Langley and Rouleau (2007) and Greenwood et al. (2011). Of the pressures, the unpredictability of the hospital context especially stood out, as well as severe state regulations, scarcity of resources due to the philanthropic nature of the context and the multiple interests (and different logics) of the groups involved.

The unpredictability and dynamicity of the hospital context had a strong impact on the strategic management as they hindered the adoption of market methodologies. This was the case of the SP, with premises of a linearity and predictability that do not represent the reality of hospitals, as pointed out by Mintzberg (1994). Regarding the SP, one manager claimed, "The management tools may be the same, but the way you implement them is more complicated. I need to use tools from a furniture industry ... but this is not a furniture industry" (Interview HEG-12).

Furthermore, the pressures from agencies that regulate the health sector significantly influenced the course of the strategies planned by the hospitals. The difficulties involved in strategic programing were highlighted when a manager commented, "We plan, but we don't always manage to make it happen. Sometimes you have to [...] comply with the demands of a certain agency. Then you can't continue on the line you had planned before" (Interview HPP-02). This opinion was corroborated by a manager at HEG, who claimed, "The implementation of long-term planning is painful in the health system because the system itself, whether it's supplementary care or public healthcare, undergoes changes constantly" (Interview HEG-15). This evidence reinforced the importance of flexibility and the ability of organizational agents to adapt (McDaniel, 2007) in strategic management, especially regarding the dependence between hospitals and their external stakeholders.

The managers' concern with matters of a predominantly institutional nature was also evident at the time of the adoption of modern and legitimate management practices such as SP and Quality Certification, for example. However, in the interpretation of the internal agents (Binder, 2007; Greenwood et al., 2011; Hinings \& Greenwood, 1988), their adoption had much more to do with the 
influence of the environment than the results that were achieved. In this respect, one manager highlighted, "The initiative [adoption of SP] was supported by the majority because it addressed something that innovated the process and was related to advancing the hospital to a more modern standard" (Interview HEG-05). On the other hand, it was not an easy process, as shown by the claims of a manager of HEG, "It was ... top-down and supported by the base for interactions to review processes, prepare work flowcharts, and really manage to professionalize" (Interview HEG-07). This indicates that while their management practices are rationalist mechanisms for improving performance, they also have a symbolic appeal (Scott, 2001; Weick, 1979).

In practice, we found that the changes considered strategic by the hospitals resulted considerably from the capacity for agency (Peng et al., 2009) of the strategic leaderships and their political interactions (Harmon et al., 2015; Selznick, 1971), in response to the (internal and external) environment. At HPP, for example, many strategic decisions were guided by the visionary characteristic of the TMT, associated with opportunities identified in the environment, contradicting opposing internal perceptions and external environmental conditions. According to one manager, "Trying things another way never made us give up our main goal" (Interview HPP-04). A point in question was the change in the State legislation in an attempt to seek special fiscal benefits for nonprofit social organizations, a result of the initiative and insistence of a HPP manager. After almost five years of lobbying, new legislation was passed in 2005 by state legislators. In this sense, different degrees of human agency were identified (Battilana \& Leca, 2009; Zilber, 2002), helping to explain some differences found in the strategy practiced in the hospitals. These differences include acquiescence or interference with the environment and the influence of internal conflicts on the continuity of actions.

One of the strategic management mechanisms found by HPP to address the dynamicity of the hospital context was the use of projects. This was a way for the manager to relate each strategic purpose/implementation decision for specific sources to capturing the required resources. The benefits of this practice were highlighted by one of the managers: "I would say that our planning became more dynamic when it came to be spelt out in detail at the project level. This allowed us to institute a systematization for attracting resources" (Interview HPP-06). Thus, HPP formed a team specializing in project development and attracting resources. The good results institutionalized this practice internally, as seen in the report of an aide "Someone has an idea. We are a little factory for formatting [projects] and seeking resources. People mobilized, became organized ... we have even brought in an investor together" (Interview HPP-16).

The strategic management of HEG, in turn, proved to be more conservative and acquiescent to the pressures of the environment. The processual formality in the SP, as initially adopted, slowed down the implementation of changes. However, the difficulties encountered and the mostly unsatisfactory results encouraged HEG to adopt a less rational stance in terms of the strategic process. There was greater interaction with the external environment by using projects to attract resources.

Because of the strong bias and resistance, the strategic management was marked by negotiations and adaptation (Jarzabkowski \& Fenton, 2006; Mintzberg, 1987; Stacey, Griffin, \& Shaw, 2000), especially in dealings with the specialists. Of the practices adopted in this situation, a manager at HEG pointed out that "We have been handling this [changes with an impact on the actions of physicians] with a lot of training and dialogue" (Interview HEG-08). The challenge is corroborated by a manager, referring to the implementation of changes related to the SP process and Hospital Certification of HEG: "I would be lying if I said that it was not political interaction" (Interview HEG-02). The plurality of internal interest groups and their implications for strategic management are also evident in the report of a director at HPP: "You always need to be ready to negotiate at multiple levels in this special environment that is the hospital" (Interview HPP-09). In part, this conflict can be explained by the cognitive bias of the groups with power in these hospitals and particularly how each agent perceives and interprets (Hinings \& Greenwood, 1988; Weick, 1979) the environment, which influences not only the need for change but also how to bring it about.

A summary of the main characteristics of these strategic processes is shown in Table 2 . 
Table 2

Strategic Management at Hospitals: Managerial and Institutional Characteristics

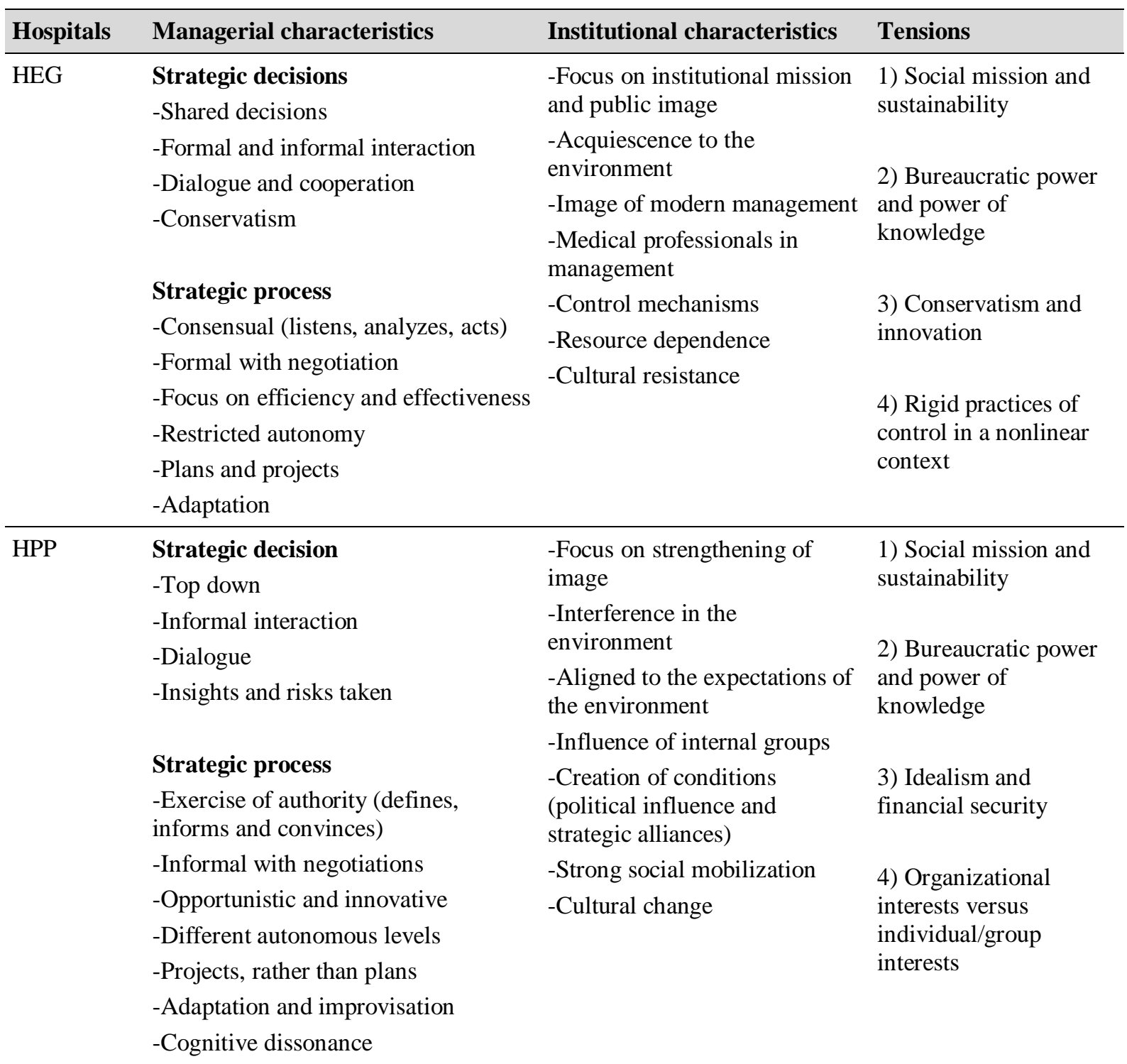

Note. Source: Research.

An analysis of the strategic management experienced at both hospitals revealed great concern from the top administrators in charge of the process, it was concentrating on the integration of organizations' mission, goals and resources vis-à-vis environmental needs and society's expectations. As a result, critical tensions were identified during the materialization of the strategic process that challenged the management in both hospitals. How each organization dealt with such tensions and how the strategic management helped to overcome these difficult obstacles are discussed in the next topic.

\section{Main tensions and implications for strategic management}

The tensions identified (see Table 2) can be clustered into three more critical tensions found in the strategic management process in both hospitals: tension between internal conditions and environmental pressures; tension between bureaucratic power (TMT) and power of knowledge (professional specialists); and tension between mission and sustainability. The way such tensions and conflicts are and how they were handled by strategic managers are discussed in this section. 


\section{Tension between internal conditions and environmental pressures}

The experiences revealed a possible conflict of values, which were not totally renewed when contemplating internal needs and environmental pressures. While the TMT was concerned with internal changes to improve the image of the hospitals, internal groups offered resistance, fearful of a change in the status quo ("Everything that is new scares the people"; "In the administrative area there was a lot of resistance because there was a predominant financial perspective" [HPP]).

In some cases, disagreement over values hindered even the determination of what was legitimate when determining how to use resources and act, showing that the integration of these elements will always be a challenge to hospital managers ("Resistance was very strong. Initially everyone thought: 'why to create a new unit if what the Hospital needs is more money?" [HPP]).

At HPP, for example, pressure for change created tension between the idealism of members of the TMT and the conservative attitude of the internal groups when it came to strategic decisions ("The love for the HPP facilitates a little this continuous, constant work of convincing these two blocks, because here there is the organization and there is another huge block that is the doctors" (Interview HPP-06), and: "The main characteristic is that people do not let themselves down ... so that's how it grew" (Interview HPP-11).

At HEG, TMT wanted to pursue a goal: to transform the Hospital in a Business Organization based on professional management. On this matter one manager stated: "When I came here I took on a compromise with the superintendent: to help him in the process of transforming the hospital into a company. At the time the current concept here was that of hospital as a humanitarian organization, often confusing in its practices the charity with humanism" (Interview HEG-13). The goal was quite altruistic and required a drastic change in the organizational culture and, therefore, in the minds and behavior of the people.

Aiming more cooperation and integration within the core area of the hospital (HEG), the administration increased the number of staff meetings. This fact generated irritation and tensions among health professionals, particularly the physicians. The difficulty was highlighted by the administrative manager: "I would say that if I were to enumerate degrees of difficulty that we have, I would say that the clinical body is the biggest obstacle that we have inside the institution, so that we can implant anything. That's why it took us more than five years to implement the system because the resistance was too strong" (Interview HEG-09). She added: "how do we do it? Showing to them what we could bring to the institution in terms of gain and gain for them" (HEG).

Whereas some members of the TMT attempted to interfere in the environment (Oliver, 1991) in favor of the hospital, other members and specialists were acquiescent and apprehensive about the environment. In some cases, the TMT took risks to show that change was necessary. According to a manager of HPP, "Two things move us: the first is the certainty that this is the best choice; the second is because this is the best and we are going to do this with people and sometimes in spite of people" (Interview HPP-01, emphasis added). This revealed a conflict between concern with organizational performance and relevant institutions, which highlights the influence of the environment on organizational choices, and decisions based on the assumption of a strategy-mediated impact of institutional pressure (Ang et al., 2015; Paroutis \& Heracleous, 2013).

One of the implications of the tension between innovation and maintaining the status quo at HEG was the moroseness of the strategy process. The experience of the hospital revealed that current beliefs and values are closely related to the structures and internal processes. Volunteer work, for example, has triggered some problems and raised tensions within the hospital. This is the case when volunteers were assisting and taking care of patients at HEG, for instance. This situation was very strong especially at the beginning of the professionalization of management. The change started when new processes were implemented including strategic planning, control and budgeting among others. This was the foci of tensions throughout the organization. As a justification of difficulty of working with volunteers, the 
planning manager highlighted that "you have a group of 350 ladies and gentlemen willing to do things ... but sometimes goodwill goes over the rules and procedures" (Interview HPP-14).

On this point, authors like Hinings and Greenwood (1988) and Greenwood et al. (2014) identify it as an organizational archetype. The proposition of the new generation of managers for processual changes and behavior that is essential to the sustainability and revitalization of the hospital's image led to conflict and resistance. This meant that the TMT were required to be flexible, negotiate and adapt.

Hospital organizations influence and are influenced by the environment. The capacity for agency proved to be an essential factor in this process. The adoption of legitimate practices such as strategic management and budgeting showed that the organizational and institutional vision can be independent and co-dependent or even integrated depending on the context, values, perspective and managerial actions adopted by the management.

In the case of HPP the way its managers react to the tensions related to the amount of external pressures and the lack of internal resources available was coped by encouraging managers in lower echelons to search for a more proactive and creative strategic actions. In the opinion of a manager of HPP, "Philanthropic institutions that need donations are not very daring. I think that our major differential here is to be daring" (Interview HPP-14). And: "Things happened more or less like this: look, now it already exists and then you have to help" (Interview HPP-12). This took place through informality and empowerment of the lower levels units with emphasis on change and anticipated strategic responses to external forces. In this respect, a manager highlighted that, "Our team has a great deal of freedom to create. So when you have this freedom, your mind is highly stimulated, and this is very good" (Interview HPP-11).

At HEG, however, the approach followed by the TMT was more formal creating a gap represented by a metaphor between the head and the body of the organization. Tensions and conflicts arose quite often between the top management in charge of overseeing the strategic management within the organization and the lower level units in charge of the core operations of the hospital. Operational units were adopting too conservative and reactive behavior in relation to their issues compromising the process. According to a manager at HEG, "The change ... the acceptance of medical professionals, who were already accustomed to a form of registration of patients and then everything changed. This was the biggest barrier we encountered" (Interview HEG-07). And, about the same matter another manager complemented: "We had to schedule meetings, call people outside to explain the change to the clinical body and overcome the barrier, resistance" (Interview HEG-11).

Another aspect that contributed to the generation of tensions among the managers was the change of the hospital structure (HEG) from a bureaucratic system to a matrix system. Commenting on this fact, the administrative manager said: "The management of the organization, within the matrix line that was implemented, the beginning was very difficult because people understood that they had to respond to two people. Why this difficulty? Because you left the hierarchically traditional model for a slightly more modern model and had to give faster answers" (Interview HEG-09).

The way top managers in both hospitals sought to overcome such threats to the strategic management process was the use of politics, bargain and negotiation with a variety of professional units in charge of implementing particular goals and strategies. In addition, the projection of the social image of hospitals and the adoption of projects to raise funds were also very important in reducing tension and alleviating the most critical conflicts. A manager at HEG highlighted this finding: "The campaigns that the hospital started running in society ... made the new positive image of the hospital resulted in financial resources" (Interview HEG-05).

\section{Tension between bureaucratic power and knowledge power}

This kind of tension fueled even further the differences between groups, which is a common occurrence in pluralistic organizations generating conflicts among different groups (Etzioni, 1964; Jarzabkowski \& Fenton, 2006; Mintzberg, 1987). This was especially true in the case of three groups in 
hospitals with diversified interests groups like administrators, trustees and physicians share authority, thereby constituting what Gordon (1962) called the top management triangle. Although all have power, none of them is effectively at the summit. The cognitive biases, their own way of interpreting reality and commitment to different and conflicting logics (Hinings \& Greenwood, 1988; Pache \& Santos, 2010; Paroutis \& Heracleous, 2013), was delimited by the shared values and beliefs of such groups, and had a considerable influence on the way strategies emerged and materialized. This is also a clear and strong representation of cognitive dissonance in accordance with Festinger (1957).

In this case, autonomy not only hindered the alignment between decision and action on occasion but also triggered strong tensions and conflicts between managers and health professionals at HEG. The standardization of health services and the establishment of control systems as a result of the incorporation of managerial approaches was always a great challenge, despite the benefits achieved in terms of the quality image and pioneerism for which philanthropic hospitals strive.

The tension that arose required skill on the part of the TMT to promote a change to the rules and legitimized managerial practices. In this context, political negotiation and bargain proved to be a fundamental practice at both hospitals. The importance of the interactions and the political aspect in the dealings with specialist professionals was highlighted by a director of HPP: "The clinical staff is a special situation ... because we can't give them [physicians] orders, and they can't tell us what to do either" (Interview HPP-09). He went on to present the tactic used "I have to lead by convincing people, not through authoritarianism" (Interview HPP-09)

The experience of HEG on this matter revealed that the TMT adopts a policy of greater participation and contribution from the professional sectors in strategic management process, combining a top-down and bottom-up approach. According to a manager, "Although there is a conflict of interests, there is sufficient maturity to know that in a critical situation, changes have to be made" (Interview HEG-14). On the one hand, this process provided a greater contribution from the professional sectors responsible for the effective strategic actions based on the autonomy and power of knowledge of the health professionals. On the other hand, this same strategic management led to great difficulty to top management in terms of organizational integration and alignment, given the greater participation and different interpretations of the external and internal reality what enhanced conflicts of goals, priorities and strategic actions beliefs generating problems in terms of sensemaking and enactment of individuals and groups (Weick, 1995). This hindered the conciliation of a much larger number of interests, which were mostly divergent as a loosely coupled system perpetuating a problem in the practice of strategic management in both hospitals.

\section{Tension between mission and sustainability}

The experiences of both hospitals indicated that one of the greatest managerial challenges of this kind of organization lay in balancing the social mission with the organizational sustainability. According to one manager of HPP, "We have two major concerns: growth and development, and survival. These two issues often come into conflict" (Interview HPP-01).

On the one hand, there is a need to manage resources efficiently and effectively, seeking an equilibrium in economic and financial terms with the cooperation of the people. At the same time, there is the essential requirement to respond to the demands, pressures and expectations of society in terms of high quality, reliable and affordable health services, thus fulfilling the institutional mission. In this respect, a manager claimed that, "When it comes to survival, we have the problem of fulfilling our mission. If, to survive, I allowed the mission not to be accomplished, it would be because there are no other solutions" (Interview HPP-04). In this respect, a director of HEG stated that, "If you go ahead with transformation processes that are meant to be applied to a business model, you'll destroy the institution. We managed, by emphasizing our mission, to live up to the situation" (Interview HEG-01).

The fulfilment of the social mission of the hospitals implies an enormous deficit caused by the services provided to the SUS that led to a dependence on alternative sources of income to keep the hospitals financially afloat. The difficulties of working with the SUS were highlighted by a manager of 
HPP: "All the health insurance companies try to underpay you. Some manage. The SUS is the champion. It is a model that includes perversity" (Interview HPP-02). This feeling was corroborated by a manager of HEG, who said of the SUS: "Although its model, from a social viewpoint is fantastic, ... it needs funding. It is impossible to treat everyone for free" (Interview HEG-06).

On the other hand, in a country where most hospitals are philanthropic, elements such as image, institutional mission, social representativeness and networking are essential and those may come as resources. In this context, there is a vicious circle, where image determines the volume of resources and these in turn are more readily available to effective and sustainable institutions. A conflict arises when effectiveness and improved image mean changes in the management process.

The use of the mission by the TMT at HEG as the reference to promote changes to the internal culture reveals how the encouragement of integrating actions can aid this process. Although it was a morose process, the results achieved were a landmark in the history of the hospital. The greatest resistance was that among the founders and representatives of local society, for whom the social image of the hospital overlapped with organizational matters such as finance.

The capacity for external articulation by the TMT at HPP was one of the keys to implementing the strategies through the social mission. One instance of this was the support of celebrities in campaigns, such as the opening of the Research Institute, an initiative backed by a well-known former soccer player, a respected personality worldwide. As a manager of HPP claimed, "We really have a lot to give, and a lot to receive, but we need to create communication channels and be a bit more daring, right?" (Interview HPP-02). This was strategic when it came to financials results and strengthening the hospital's image. Campaigns and social work in the field of health and well-being of children and adolescents, which received domestic and international awards, also showed how HPP interacts with the environment and how these actions pay handsome dividends.

In the end, the institutional mission of the hospitals proved to be an integrating mechanism capable of bringing divergent professional groups together. Moreover, the institutional mission can also motivate cultural change and, even, be a source for fundraising. According to a manager of HEG, the mission "is a way for you to help society and the hospital needs to have a positive image. This comes back to us in the form of help, donations and recognition" (Interview HEG-03). When the mission came to be seen in this light, it fostered institutional change, brought groups together and motivated a new perspective on the interaction between both hospitals and the environment.

\section{Discussion and Implications}

The role of strategic management, in both cases, was characterized as the main guidance and orientations set by the top management to the entire organizations. Adjustment and integration between the top management and professional core is critical. On this matter, strategic management models imported from the business sector based on a high level of rationality do not suit the complex nature of hospitals.

Strategic management also works as a symbol of fancy management, animating people and gathering them together around the central issues of organizations. One of the requirements is to have a leadership to conduct the managerial process, seeking to combine within the organization and adjust the strategic management approach and other managerial tools to the specificities of hospitals as unique and complex entities.

Another key aspect is to transform the main goals into decisions and strategic actions in the operational core to empower health professionals to act, make sense and produce meaningful and relevant outcomes from their efforts. This is reified by micro strategy initiatives carried out by a variety of agents working as strategists, in different areas and levels, with the support of the top management. 
The strategic outcomes, however, would be only considered actually strategic retrospectively, or $e x$ post facto in a typical rationalization process.

By making all the strategic efforts, the hospital managers faced typical tensions and conflicts that are quite natural in such complex, pluralistic, professional and loosely coupled organizations. Learning how to cope with such challenges is critical to the success of the strategic endeavor and requires experience and knowledge of hospital managers. As the cases revealed, managers in both hospitals learned by doing how to handle tensions and conflicts during the unfolding of the strategic management process.

Finally, it is important to emphasize that tension and conflict are part of any social organization environment. Hospitals as social entities display a typical ambidextrous characteristic that focuses on a dual logic: a managerial one that encompasses the concern for efficiency in the use of resources and effectiveness in terms of goals achievement; and the institutional one, linked to the relevance of their contributions to society represented by acceptability, legitimacy and credibility. Accommodating the two logics in a meaningful way requires more than techniques, but also sensibility and art from managers. These elements continue to pose a challenge to all hospital managers. The performance of hospitals depends very heavily on the balance of the two logics.

\section{Concluding Remarks}

Materializing strategies within complex contexts like hospitals has posed a challenge to managers. Strategies usually stem either from previously established ideas, with decisions based on rational analysis combining intentions, opportunities and actions to achieve organizational efficiency and effectiveness, or as the result of unplanned initiatives that emerge, combining initiatives, feelings, insights, hunches, improvisation and negotiations that are retrospectively interpreted and rationalized.

Strategy management in pluralistic contexts is a dynamic process in which organizational and institutional factors play an important role measured by their outcomes. It encompasses different views of the environment by agents and the actions of the organization in this context. Questions related to goal ambiguity, power, politics, autonomy, and conflicts need to be addressed because they have a strong impact on the strategies that are practiced, which are essential to the improvement of the quality of services and fulfillment of the social mission.

Improving the way strategies are managed in a context such as hospitals requires professional managers who pay special attention to the complex nature of this kind of organization and how they impact the strategic endeavor. This effort requires a combination of strong leadership and sensibility to use appropriate managerial tools required to strategic actions. In the absence of strategic management tools to the hospital context, aspects such as flexibility, adaptability, creativity and informal interactions should be the basis for any strategic initiative. In this sense, whether in the internal or external context, daring and innovation - more than acquiescence - of the hospitals are essential to their social and financial sustainability.

Given the challenges faced by managers due to the high level of uncertainty and risks from the environment plus the complex nature of hospitals, it is necessary to seek a strategic management approach with refined sensitivity. This approach aims to reduce these tensions and conflicts finding better ways to integrate efforts and help improve the health services seeking legitimacy in the eyes of stakeholders and long-term institutional sustainability.

Some particular areas related to the practice of strategy management at hospitals deserve further and more in-depth research. Themes like the role of agency, institutional strategy, ambiguous goals, creativity, micro strategies and strategic dissonance have a considerable influence on strategic management processes. Other aspects include politics, conflicts and power, complexity and the degree 
of coupling, sensemaking and sensegiving, and micro activities. All of these require greater attention in future studies by researchers.

\section{References}

Andersen, T. J. (2004). Integrating decentralized strategy making and strategic planning processes in dynamic environments. Journal of Management Studies, 41(8), 1271-1299. https://doi.org/10.1111/j.1467-6486.2004.00475.x

Ang, S. H., Benischke, M. H., \& Doh, J. P. (2015). The interactions of institutions on foreign market entry mode. Strategic Management Journal, 36(10), 1536-1553. http://dx.doi.org/10.1002/smj.2295

Battilana, J., \& Leca, B. (2009). The role of resources in institutional entrepreneurship: insights for an approach to strategic management that combines agency and institution. In L. A. Constanzo \& R. B. Mackay (Eds.), Handbook of research on strategy and foresight (pp. 260-274). Northampton, Massachusetts: Edward Elgar Publishing Ltd.

Binder, A. (2007). For love and money: Organizations' creative responses to multiple environmental logics. Theory and Society, 36(6), 547-571. http://dx.doi.org/10.1007/s11186-007-9045-x

Chandler, D., \& Hwang, H. (2015). Learning from learning theory: A model of organizational adoption strategies at the microfoundations of institutional theory. Journal of Management, 41(5), 14461476. http://dx.doi.org/10.1177/0149206315572698

Colyvas, J., \& Maroulis, S. (2015). Moving from an exception to a rule: Analyzing mechanisms in emergence-based institutionalization. Organization Science, 26(2), 601-621. http://dx.doi.org/10.1287/orsc.2014.0948

Correia, T. (2012). Medicina: O agir numa saúde em mudança. Lisboa: Editora Mundos Sociais.

Decreto $n$. 8.242, de 23 de maio de 2014. (2014). Regulamenta a Lei no 12.101, de 27 de novembro de 2009, para dispor sobre o processo de certificação das entidades beneficentes de assistência social e sobre procedimentos de isenção das contribuições para a seguridade social. Retrieved from http://www.planalto.gov.br/ccivil_03/_ato2011-2014/2014/decreto/d8242.htm

Denis, J.-L., Langley, A., \& Rouleau, L. (2007). Strategizing in pluralistic contexts: Rethinking $\begin{array}{llll}\text { theoretical Human } & \text { frames. }\end{array}$ https://doi.org/10.1177/0018726707075288

Dunn, M. B., \& Jones, C. (2010). Institutional logics and institutional pluralism: The contestation of care and science logics in medical education, 1967-2005. Administrative Science Quarterly, 55(1), 114-149. https://doi.org/10.2189/asqu.2010.55.1.114

Eriksson, P., \& Kovalainen, A. (2008). Qualitative methods in business research. London: Sage Publications Ltd.

Etzioni, A. (1964). Modern organizations. New Jersey: Prentice-Hall.

Faulconbridge, J., \& Muzio, D. (2016). Global professional service firms and the challenge of institutional complexity: 'Field relocation' as a response strategy. Journal of Management Studies, 53(1), 89-124. http://dx.doi.org/10.1111/joms.12122

Festinger, L. (1957). A theory of cognitive dissonance. Evanston, IL: Row \& Peterson. 
Flyvbjerg, B. (2011). Case study. In N. K. Denzin \& Y. S. Lincoln (Eds.), The SAGE handbook of qualitative research (pp. 301-316). London: SAGE Publications Ltd.

French, R., \& Grey, C. (1996) Rethinking management education. London: Sage.

Gordon, P. J. (1962). The top management triangle in voluntary hospitals. Academy of Management Journal, 5(1), 66-75. https://doi.org/10.2307/254603

Greenwood, R., Hinings, C., \& Whetten, D. (2014). Rethinking institutions and organizations. Journal of Management Studies, 51(7), 1206-1220. http://dx.doi.org/10.1111/joms.12070

Greenwood, R., Raynard, M., Kodeih, F., Michelotta, E., \& Lounsbury, M. (2011). Institutional complexity and organizational responses. Academy of Management Annals, 5(1), 317-371. https://doi.org/10.1080/19416520.2011.590299

Harmon, D., Green, S., Jr., \& Goodnight, G. T. (2015). A model of rhetorical legitimation: The structure of communication and cognition underlying institutional maintenance and change. Academy of Management Review, 40(1), 76-95. http://dx.doi.org/10.5465/amr.2013.0310

Herman, D. (Org.). (2007). The Cambridge companion to narrative. New York: Cambridge University Press.

Hinings, C., \& Greenwood, R. (1988). The dynamics of strategic change. New York: Basil Blackwell.

Hospital Erasto Gaertner. (2014). Relatório anual 2013. Curitiba, Brasil: Erasto Gaertner.

Hospital Pequeno Príncipe. (2014). Relatório de atividades 2013 (Unpublished report). Curitiba, Brasil: Hospital Pequeno Príncipe.

Jarzabkowski, P., \& Fenton, E. (2006). Strategizing and organizing in pluralistic contexts. Long Range Planning, 39(6), 631-648. https://doi.org/10.1016/j.lrp.2006.11.002

King, B. (2015). Institutions and ideals: Philip Selznick's legacy for organizational studies. In M. S. Kraatz (Ed.), Institutions and ideals: Philip Selznick's legacy for organizational studies (Research in the Sociology of Organizations, Vol. 44, pp. 149-175). http://dx.doi.org/10.1108/S0733$558 \times 20150000044007$

Lawrence, T., Suddaby, R., \& Leca, B. (2011). Institutional work: refocusing institutional studies of organizations. Journal of Management Inquiry, 20(1), 52-58. http://dx.doi.org/10.1177/1056492610387222

Lei n. 12.101 de 27 de novembro de 2009. (2009). Dispõe sobre a certificação das entidades beneficentes de assistência social; regula os procedimentos de isenção de contribuições para a seguridade social; altera a Lei no 8.742, de 7 de dezembro de 1993; revoga dispositivos das Leis nos 8.212, de 24 de julho de 1991, 9.429, de 26 de dezembro de 1996, 9.732, de 11 de dezembro de 1998, 10.684, de 30 de maio de 2003, e da Medida Provisória no 2.187-13, de 24 de agosto de 2001; e dá outras providências. Diário Oficial da União. Brasília, DF: Imprensa Nacional.

Lieberman, M. B., \& Asaba, S. (2006). Why do firms imitate each other? Academy of Management Review, 31(2), 366-385. https://doi.org/10.5465/amr.2006.20208686

Lieberson, S. (1992). Small Ns and big conclusions: An examination of the reasoning used in comparative studies based on a small number of cases. In C. C. Ragin \& H. S. Becker (Eds.), What is a case? (pp. 105-118). Cambridge: Cambridge University Press.

Locke, R. R., \& Spender, J. C. (2011). Confronting managerialism: How business elite and their schools threw our lives out of balance. London: Zed Books. 
Manning, P., \& Cullum-Swan, B. (1994). Narrative, content, and semiotic analysis. In N. Denzin \& Y. Lincoln (Eds.), Handbook of qualitative research (pp. 463-77). California: Sage.

McDaniel, R. R. (2007). Management strategies for complex adaptive systems: Sensemaking, learning, and improvisation. Performance Improvement Quarterly, 20(2), 21-41. http://dx.doi.org/10.1111/j.1937- 8327.2007.tb00438.x

Meyer, V., Jr., Pascuci, L., \& Mamédio, D. F. (2016). Managerialism in complex systems: Experiences of strategic planning in non-profit hospitals. In R. Pinheiro, L. Geschwind, F. Ramirez, \& K. Vrangbaek (Eds.), Towards a comparative institutionalism: Forms, dynamics and logics across the organizational fields of health care and higher education (pp. 271-295). http://dx.doi.org/10.1108/S0733-558X20150000045024

Meyer, V., Jr., Pascuci, L., \& Murphy, J. P. (2012). The implementation of strategies in complex systems: Lessons of Brazilian hospital organizations [Special issue]. Business Administration Review, 9, 19-37. https://dx.doi.org/10.1590/S1807-76922012000500003

Mintzberg, H. (1978). Patterns in strategy formation. Management Science, 24(9), 934-948. https://doi.org/10.1287/mnsc.24.9.934

Mintzberg, H. (1987, July). Crafting strategy. Harvard Business Review, 66-77. Retrieved from https://hbr.org/1987/07/crafting-strategy

Mintzberg, H. (1994). The rise and fall of strategic planning. New York: The Free Press.

Mohr, J., \& White, H. (2008). How to model an institution. Theory and Society, 37(5), 485-512. http://dx.doi.org/10.1007/s11186-008-9066-0

Morse, J. M. (2011). What is a qualitative health research? In N. K. Denzin \& Y. S. Lincoln (Eds.), The SAGE handbook of qualitative research (pp. 401-414). London: SAGE Publications Ltd.

Oliver, C (1991). Strategic responses to institutional processes. Academy of Management Review, 16(1), 145-179. https://doi.org/10.2307/258610

Orton, J. D., \& Weick, K. E. (1990). Loosely coupled systems: a reconceptualization. The Academy of Management Review, 15(2), 203-223. https://doi.org/10.2307/258154

Pache, A., \& Santos, F. (2010). When worlds collide: the internal dynamics of organizational responses to conflicting institutional demands. Academy of Management Review, 35(3), 455-476. https://doi.org/10.5465/amr.2010.51142368

Paroutis, S., \& Heracleous, L. (2013). Discourse revisited: Dimensions and employment of first-order strategy discourse during institutional adoption. Strategic Management Journal, 34(8), 935-956. http://dx.doi.org/10.1002/smj.2052

Peng, M. W., Sun, S. L., Pinkham, B., \& Chen, H. (2009). The institution-based view as a third leg for a strategy tripod. Academy of Management Perspectives, 23(3), 63-81. https://doi.org/10.5465/amp.2009.43479264

Porter, M. (1980). Competitive strategy. New York: Free Press.

Porter, M., \& Teinsberg, E. O. (2006). Redefining healthcare: Creating value-based competition on results. Boston: Harvard Business School Press.

Quattrone, P. (2015). Governing social orders, unfolding rationality, and Jesuit accounting practices: A procedural approach to institutional logics. Administrative Science Quarterly, 60(3), 411-445. http://dx.doi.org/10.1177/0001839215592174 
Ruef, M., \& Scott, W. R. (1998). A multidimensional model of organizational legitimacy: Hospital survival in changing institutional environments. Administrative Science Quarterly, 43(4), 877904. https://doi.org/10.2307/2393619

Scott, W. R. (2001). Institutions and organizations. London: Sage.

Selznick, P. (1971). A liderança na administração. São Paulo: Fundação Getúlio Vargas.

Simon, H. (1957). Administrative behavior (4th ed.). New York: The Free Press.

Smets, M., Morris, T., \& Greenwood, R. (2012). From practice to field: A multilevel model of practicedriven institutional change. Academy of Management Journal, 55(4), 877-904. https://doi.org/10.5465/amj.2010.0013

Stacey, R. D., Griffin, D., \& Shaw, P. (2000). Complexity and management: Fad or radical challenge to systems thinking? New York: Routledge.

Tsoukas, H., \& Hatch, M. J. (2001). Complex thinking, complex practice: The case for a narrative approach to organizational complexity. Human Relations, 54(8), 979-1013. http://dx.doi.org/10.1177/0018726701548001

Walker, K., Schlosser, F., \& Deephouse, D. (2014). Organizational ingenuity and the paradox of embedded agency: The case of the embryonic Ontario solar energy industry. Organization Studies, 35(4), 613-634. http://dx.doi.org/10.1177/0170840613517599

Weick, K. E. (1976). Educational organizations as loosely coupled systems. Administrative Science Quarterly, 21(1), 1-19. http://dx.doi.org/10.2307/2391875

Weick, K. E. (1979). The social psychology of organizing (2nd ed.). New York: Tandom House.

Weick, K. E. (1995). Sensemaking in organizations. Thousand Oaks, CA: Sage.

Wildavsky, A. (1973). If planning is everything maybe it's nothing. Policy Sciences, 4(2), 127-153. https://doi.org/10.1007/bf01405729

Wilson, D. (1992). A strategy of change: Concepts and controversies in the management of change. New York: Cengage Learning.

Zilber, T. (2002). Institutionalization as an interplay between actions, meanings and actors: The case of a rape crisis center in Israel. Academy of Management Journal, 45(1), 234-254. https://doi.org/10.2307/3069294

Zoogah, D., Peng, M., \& Woldu, H. (2015). Institutions, resources, and organizational effectiveness in Africa. Academy of Management Perspectives, 29(1), 7-31. http://dx.doi.org/10.5465/amp.2012.0033

\section{Authors' Profiles}

Lucilaine Maria Pascuci

Av. Fernando Ferrari, 514, Goiabeiras, 29075-910, Vitória, ES, Brazil. E-mail address: lucilaine.pascuci@ gmail.com

Victor Meyer Júnior

Rua Imaculada Conceição, 1155, Prado Velho, 80215-901, Curitiba, PR, Brazil. E-mail address: victormeyerjr@gmail.com

João Marcelo Crubellate

Av. Colombo, 5790, Zona 7, 87020-900, Maringá, PR, Brazil. E-mail address: jmcrubellate@uem.br 